DOI: $10.14746 /$ por.2018.1.10

\title{
TRANSLATION AS A KEY AND A MIRROR: RECEPTION OF SERBIAN LITERATURE IN TODAY'S UKRAINE
}

\author{
Alla Tatarenko ${ }^{1}$ \\ (Ivan Franko National University of Lviv)
}

Keywords: reception, translation, Serbian literature

Słowa kluczowe: recepcja, przekład, literatura serbska

\begin{abstract}
Alla Tatarenko, TRANSLATION AS A KEY AND A MIRROR: RECEPTION OF SERBIAN LITERATURE IN TODAY'S UKRAINE. "PORÓWNANIA" 1 (22), 2018. Vol. XXII, P. 185-198. ISSN 1733-165X. The objective of this paper is to identify the main trends in the representation of Serbian literature in Ukraine during the last twenty years, to trace the ways and means of shaping the corpus of the Serbian literature translated into Ukrainian, to determine the factors influencing the reception of Serbian belles-lettres in Ukraine, as well as changes taking place in translation policies, publishing strategies and formats of presenting translations. Translation is considered the key to understanding and identifying another nation as well as a mirror in which the reader not only sees the reflection of the Other, but also investigates their own face.
\end{abstract}

Abstrakt: Ałła Tatarenko, PRZEKŁAD JAKO KLUCZ I ZWIERCIADŁO: RECEPCJA LITERATURY SERBSKIEJ WE WSPÓŁCZESNEJ UKRAINIE. „PORÓWNANIA” 1 (22), 2018. T. XXII, S. 185-198. ISSN 1733-165X. Celem artykułu jest określenie głównych tendencji w prezentacji literatury serbskiej w Ukrainie w ciągu ostatnich dwudziestu lat, prześledzenie środków i sposobów formowania korpusu przetłumaczonej literatury serbskiej, określenie czynników wywierających wpływ na recepcję piśmiennictwa serbskiego w Ukrainie, również zmian zachodzących w działalności tłumaczeniowej, strategiach wydawniczych, formach prezentacji przetłumaczonych wydań. Przekład w tym należy traktować jako klucz do zrozumienia innego narodu, jako klucz do identyfikacji i jednocześnie jako zwierciadło, w którym czytelnik widzi nie tylko odbicie Innego, ale też szuka własnej twarzy.

1 E-mail: allaala@ukr.net 
Despite the topicality of studying literary connections between Ukraine and other Slavonic nations as well as a large number of the papers devoted to this theme, covering the matter of previous centuries, the issue of the reception of Serbian literature in Ukraine today remains insufficiently explored. Although various aspects of Ukrainian-Polish cultural relations have been researched rather often by Ukrainian scholars (e.g., studies by Olesya Nakhlik (Nakhlik 2010, Nakhlik 2014), Andriy Savenets (Savenets 2006), Viktoriya Ostapchuk (Ostapchuk 2016) etc.), South Slavonic literatures have attracted much less attention of literary critics. Yevhen Pashchenko, ${ }^{2}$ a Croatian specialist in Ukrainian language and literature, scrutinized Ukrainian-Croatian literary contacts during different periods (Paščenko 2010). In the article „Ukrainian Reception of Croatian and Serbian Literature in Transition-Period" (Paščenko 2017) he also highlighted certain aspects of the reception of Serbia's contemporary writing in Ukraine in the broader context of presenting the reception of Croatia's contemporary literature and the development of Ukrainian Studies in Croatia and Serbia. Dejan Ajdačić, a Serbian Slavist, notes the activities of Ukrainian translators and researchers of Serbian literature while reviewing Ukrainian-Serbian literary connections (Ajdačić 2005; Ajdačić 2007; Ajdačić 2010; Ajdačić 2015). Translation activities of Lviv's specialists in Serbian language and literature are discussed in the article „Bridges of Intercultural Cooperation: On the Translation Experience of the Department of Slavonic Philology at the Ivan Franko University" (Lobur, Motornyi, Tatarenko 2014). Separate papers are devoted to the specific features of the reception of writings by Milorad Pavić in Ukraine (Tatarenko 2003; Tatarenko 2006), Danilo Kiš (Tatarenko 2001), changes in the representation of Serbian literature at the turn of the $21^{\text {st }}$ century (Tatarenko 2002). The full list of Ukrainian translations of Serbian literature as well as critical articles by Ukrainian Slavists are recorded in the bibliography "Serbian folklore and literature in Ukrainian translations and researches. 1837-2004" (Ajdačić et al.). The objective of this paper is to identify the main trends in the representation of Serbian literature in Ukraine during the last twenty years, to trace the ways and means of shaping the corpus of the Serbian literature translated into Ukrainian, to determine the factors influencing the reception of Serbian belles-lettres in Ukraine, as well as changes taking place in translation policies, publishing strategies, formats of presenting translations. Translation is considered the key to understanding and identifying another nation as well as a mirror in which the reader not only sees the reflection of the Other, but also investigates their own face.

Ukrainian-Serbian literary contacts have a long history. In the $20^{\text {th }}$ century, they continued evolving and were influenced by historical conditions and political transformations, like all other ties between Ukrainian and foreign cultures. Translation has always been a 'barometer' of relations between two cultures: interest in the life of another nation caused interest in its literature. The ideological commonness,

2 He als authored a study on the Baroque Ukrainian-Serbian relations (Paščenko 2004). 
which was the measure of the desirability of translations from a specific language in the Soviet state, contoured an approach to the selection of works to be introduced to the Ukrainian reader. As a result, the classics and books by ideologically relevant authors prevailed among the existing translations. Particular attention was paid to writings on the Second World War and the deeds of partisans. This approach was also deployed by the Soviet creators of cultural policy for translations from other Slavonic languages, and it is difficult to determine the national features of the reception of Serbian culture in particular, as it was eventually treated as a part of the Yugoslav cultural conglomerate. In addition, it should be born in mind that the Ukrainians read foreign authors' works translated not only in their native language, but also in Russian translations, which were available throughout the entire territory of the Soviet Union.

This situation changed in the 1990s after the collapse of the USSR and the SFRY and after the formation of national states on their territories with their own cultural policies. Describing the state of art with translations in post-communist Ukraine, Yevhen Pashchenko distinguishes three forms of reception of modern literature: traditional, identifying and transitional, the latter being ", a synthesis of the two former ones, with the preponderance of aesthetic, communicative and other criteria, which are characteristic of intercultural communication" (Paščenko 2017: 81).

The first years of Ukraine's independence were marked with dominant interest in its own culture, especially in that part which was banned and remained inaccessible for the Ukrainian reader for a long time. The economic hardships in the country did not favour serious translation projects, so translations were published mainly in magazines (in addition to the magazine of world literature "Vsesvit", it is also worth mentioning the magazine "Slovyanske Viche - XXI stolittia”, where "Mansard", the first novel by Danilo Kiš, was published; it was translated by Olena Dziuba (1997)). A new stage in the reception of Serbian literature in Ukraine began twenty years ago due to launching the translation program of the Lviv publishing house "VNTL Klasyka". The first work published in this "translation" series was Milorad Pavićs novel "Dictionary of the Khazars" (1998, translated by Olha Ros), and this event determined to some extent the further way of introducing Serbian literature to Ukrainian readers. Within five years, "Klasyka" published translations of classical twentieth-century Serbian works: “The Encyclopedia of the Dead" (1998) and „A Tomb for Boris Davidovich" (2000) by D. Kiš as translated by Alla Tatarenko; M. Pavić's novels «Last Love in Constantinople» (1999, translated by Natalia Chorpita) and «Star Pallium» (2002, translated by A. Tatarenko), the cult novel «Hypocrites» by Momo Kapor (1998, translated by N. Chorpita). This high-quality publishing project led to the formation of Lviv's modern school of prose translation ${ }^{3}$ from Serbian. The publishing

3 The poets who translated from Serbian in the previous period were famous writers from Lviv, like Roman Lubkivskyi, Volodymyr Luchuk, Oksana Senatovych. 
house functioned as a platform for Lviv's young specialists in Serbian and Croatian studies: most of them did not have (great) translation experience, but they knew the achievements of Serbian literature very well and could offer valuable works for translation. Unlike the Soviet time, when the circle of translators was clearly shaped and strongly rigid, specialists in Serbian, who admired literature, started translating in the new situation. Earlier, translations used to be done strictly according to the commissions of state publishers who clearly indicated authors whose writings were (or were not) allowed to be translated, and translators did not have freedom to choose a literary piece for translation; in the new conditions, translators directly participated in shaping the publication plan. Their personal literary taste and ability to convince the publisher became factors of the publishing policy. The cooperation with "Klasyka”, with its director Volodymyr Dmyterko and the editor, writer, and specialist in Serbian and Croatian, Ivan Luchuk, proved to be originative for translators who had been working in this area for two decades. A new type of translator has been shaped: a specialist in Serbian literature who personally selects works for translation and popularizes them. This freedom has another side: Ukrainian translators of Serbian literature rarely receive orders from the publishers, and they themselves have to seek for them as well as for the financial support for a translation project.

The selection of books by Serbian authors which were published by "Klasyka" was very successful. The best testimony is that a lot of contemporary Ukrainian writers (like Irena Karpa and Svitlana Povaliayeva) refer to these Serbian texts in epigraphs, allusions, and quotations, and make them a true part of Ukrainian literature. The success of these editions was of interest to other publishers who included Serbian writers' works into their catalogues ${ }^{4}$. Lviv's Literary Agency "Piramida" continued (in its own way) the project of "Klasyka" by publishing an anthology of contemporary Serbian stories in 2004. Anthologies are reasonably considered to be a "classical" genre in presenting a foreign literature ${ }^{5}$ (cf. Paščenko 2017). They offer an opportunity to get acquainted with a wider range of present poetics and with new authors who are yet unknown for the Ukrainian reader. Among the proposed translation projects, the publishing house „Piramida” (represented by Yuriy Vynnychuk as the editor of the "Fest-Proza" Series) selected "Anthology of Serbian Postmodern Fantastic Fiction", compiled by the famous Serbian writer Sava Damjanov ${ }^{6}$. The pe-

4 The publishing house „Folio" (Kharkiv) recently published the third edition of M. Pavić's novels "Dictionary of the Khazars" and "Last Love in Constantinople" translated by O. Ros and N. Chorpita; LA „Piramida” (Lviv) published the collection of D. Kiš” stories “The Book of Love and Death" (2008). It includes "The Encyclopedia of the Dead", "A Tomb for Boris Davidovich", and some stories from the collection "Lute and Scars" (translated by A. Tatarenko).

5 The Ukrainian-language anthology, which was methodologically classical, appeared much later: it was „Twentieth-Century Serbian Literature: a Reader”, compiled by Dejan Ajdačić and Alla Tatarenko (Kyiv, 2016).

6 The manuscript of the second edition of the "Anthology" was used for translation. It was prepared for publishing by Novi Sad's publishing house „Dnevnik”. The translation came out six months ear- 
culiarity of the Ukrainian edition is that it does not reproduce the original edition exactly: the Ukrainian editor added an introductory part which contains a preface to Ukrainian readers; besides, though the compilers of the anthologies are not allowed to include their own works into the very anthologies, the Ukrainian introduction anyway contains one of S. Damjanov's most famous stories - "Reincarnation”. The anthology compiler's article, which was a foreword in the Serbian edition, became an afterword (all these structural changes of the postmodernist character are justified in the preface of the Ukrainian reader). The transformation of the translation of the Serbian edition of the "Anthology" into the Ukrainian edition of the "Anthology" shows some progress in the reception of Serbian literature in Ukraine, which is perceived without any alienation. S. Damjanov's "Anthology of Serbian Postmodern Fantastic Fiction" was one of the three highest rated books in "The 2004 Book of the Year" (in the nomination „Foreign Literature"), along with the translations of writings by Antonin Artaud and Olga Tokarczuk, which, apart from the undeniable value of the works and the popularity of the authors, belong to literatures that are more known among Ukrainian readers. This fact also testified to positive progress in the reception of Serbian literature in Ukraine. It has become so close to the Ukrainian reader that the Serbian writers Milorad Pavić and Sava Damjanov have been included into in the original project of Lviv's artist Yurko Kokh "A String of Incidents by Extremely Interesting People". Among the authors represented in the "The Emerald String" (2004) and "The Coral String" (2005), there are almost no foreigners. The exception is the Bulgarian writer Georgi Gospodinov, Belorussian Adam Maldzis and the two Serbian writers.

The publication of S. Damjanov's "Anthology of Serbian Postmodern Fantastic Fiction" contributed to the popularization of Ukrainian literature in Serbia, as it was conceived as part of a joint Ukrainian-Serbian project. In 2005, Novi Sad's publishing house "Stylos" published the Serbian translation of the "Anthology of Ukrainian Postmodern Stories", compiled by Yuriy Vynnychuk. Translation, thus, does not only promote the popularization of the literature of a source language, but also the literature of a target language.

In 2009, another original thematic anthology, ,"The Invincible Eros of Narration", was published by "Kalvariya” (its compiler and the author of the idea was A. Tatarenko). In this collection, the reader finds stories uniting the topics of Love and Word. The main heroine of these works is a (written or oral) narration that awakens love (it can be a lecture, a read piece, or pronounced words). Ukrainian readers were invited to look at Serbian literature through the prism of love and the eroticism of Word, which had survived the metamorphosis of translation. Despite its informativeness, an anthology of this type is intended to establish an emotional connection

lier than the original. The bibliographical data of the Ukrainian edition are mentioned on the cover of the Serbian edition which is a rare case for translation. 
between a foreign author's writing and a Ukrainian reader. While the Ukrainian edition of "Anthology of Serbian Postmodern Fantastic Fiction" was a modified and supplemented variant of the Serbian edition adjusted for Ukrainian readers, "The Invincible Eros of Narration" is a Ukrainian edition which does not have a Serbian prototype. This fact also shows the high degree of professional reception of Serbian literature in Ukraine.

The knowledge of Serbia's literary novelties and trends in the development of Serbian writing, which is possessed by participants of translation projects, is chiefly the result of the successful work of Ukrainian Slavist schools. The formation of Slavist scholarly and translation centres in $20^{\text {th }}$ century Ukraine contributed to a deeper study and presentation of other Slavonic literatures. Within the last fifty years, the main centres of Serbian Studies in Ukraine were Kyiv and Lviv, where university education for specialists in the Serbian language and literature was offered, as well as a significant number of cultural events related to the Ukrainian-Serbian contacts took place. Representatives of these centres (university teachers, graduates and students) became translators of Serbian literature. Most of them started their translation experience with participating in the translation of the abovementioned anthologies, in other translation team projects, as well as in preparing thematic issues of journals and almanacs. As an example, the thematic issue of the independent cultural magazine "Ji", "Yugoslavia, Kosovo, Europe" (2000), contained a large selection of translations from Serbian fiction, in addition to usual political and cultural coverage ${ }^{7}$. To the opinion of the issue curators I. Luchuk and A. Tatarenko, the best works of a literature express the spirit of a nation, so it is necessary to get acquainted with its literature in order to understand this nation ${ }^{8}$. The issue comprised some articles by Ukrainian literary critics and translators as well. A. Tatarenko, the translator of D. Kišs's writings, wrote an essay about this author („Danilo Kiš, Knight of Doubt”); O. Ros, the translator of M. Pavić's first novel, shared her autopoietic testimony „How I translated ‘Dictionary of the Khazars'", and I. Luchuk, who translated poetry by M. Pavić, wrote a poem about his acquaintance with this author („A little bit of the world”). The translations of Serbian original works were accompanied by various types of literary reflection which correspond to different forms of the reception and articulation of Serbian literature. Translators of the writings presented in the magazine speak on their own behalf, using the individually closest discourse - critical, autobiographical, literary / poetic. Serbian literature is presented in these texts as a source of literary reflections

7 In the following issues of the journal there were also published translations of works by Serbian authors which were focal for presenting the central topic of the issues (writings by Borislav Pekić, Svetislav Basara, Sava Damjanov, Jasmina Tešanović, etc.).

8 The topicality of the materials published in the issue was proven by the following discussion in the magazine "Krytyka” due to the initiative of Diana Klochko, a Kyiv-based cultural and art historian. The fact that it did not focus on Serbian culture and mentality, but on the Ukrainian one, shows again the ambivalence of reception processes. It also proves that the literature of a different nation can serve as a mirror for the reader of translation. 
and generalizations, part of their own biography, inspiration for original creativity which demonstrates the multi-directionality of its reception.

Publishing translations from Serbian literature attracts the attention of other magazines . Virtually in every issue of the Lviv-based magazine „Forma(r)t”, published in the early $21^{\text {st }}$ century, there were stories by Serbian authors (Milorad Pavić, Čedomir Mirković, Miroljub Stojanović) as well as extensive interviews with Serbian writers (Aleksandar Gatalica, Čedomir Mirković). Even in the first issue of the electronic almanac "Potiah 76", the reader finds the translation of a story by Milisav Savić and a short article about him; the following issues contain translations of writings by Serbia's classical prose writer Miloš Crnjanski and the modern writer Dragan Velikić. A significant role in introducing Serbian literature to Ukrainian readers was played by the thematic issue of this literary almanac which came out in 2007 under the title „Balkan-Express”. It presented contemporary Serbian literature along with the newest writings of Croatian, Bulgarian, Macedonian and Bosnian literatures: prose, poetry, essays and interviews. „The Classics Van” in "Potiah 76" was filled with the works by Miloš Crnjanski: the poem "Sumatra" and the expressionist manifesto "Explanation of 'Sumatra'". It, thus, shaped the poetic vertical between Serbia's postmodern literature (represented in the anthology by the prose of the postmodernists Goran Petrović, Mihajlo Pantić, Ljubica Arsić, Mileta Prodanović, the poetry of Zvonko Karanović and Laslo Blašković, the interview of Sava Damjanov) and Serbian modernism along with one of its greatest representatives. The "Balkan" concept of the almanac fitted the writing of these writers into the regional context ${ }^{10}$, completing the diachronic poetical connection with the synchronic one.

The presentation of the "Balkan" issue of the magazine "Potiah 76" was held at the international literary festival within the 2007 Lviv Publishers' Forum. It was attended by Serbian writers for the first time. These were writers whose works were translated in the almanac: Goran Petrović, Mihajlo Pantić and Zvonko Karanović. The presentation brought together about two hundred participants: that is explained not only by the "celebrity" cast of foreign participants, but by the fact that the presentation was moderated by the most famous Ukrainian writer Yuriy Andrukhovych. His reciting the translation of Z. Karanovićs poem „Psychodelic fur" helped Ukrainian readers focus their attention on the creativity of the Serbian poet. The establishment of poetical "bridges" between the creativity of individual writers as representatives of various literatures is also one of the important factors in expanding the boundaries of the reception of a foreign author. The identification

9 The magazine „Vsesvit” continues publishing works of Serbian literature (by M. Pavić, M. Prodanović, M. Pantić, etc.); a collection of modern Serbian poetry translated by I. Luchuk was published in the magazine „Kuryer Kryvbasu”.

10 The almanac also contains writings by Miljenko Jergović, Simo Mraović, Zoran Ferić, Robert Perišić, Nenad Veličković, Lamija Begagić, Alek Popov, Lidija Dimkovska and others. 
of the "Other" as the "Near" related to the best samples of the target culture and promoted interest in the source literature.

The publication of the almanac has attracted the readers' interest and the arrival of the most famous writers of Serbian literature at the Publishers' Forum further invigorated this interest. It is evidenced by a number of interviews with these writers, coverage in the press, the increasing number of publishing houses which bring out translations from Serbian, as well as the growing interest in Serbian literature among "unprofessional" readers, the rise of this interest beyond the milieu of Slavists. The beginning of a new stage in the reception of Serbian literature in Ukraine was evident. At that moment, there had appeared a new generation of translators among graduate Slavists who possessed some translation experience, ${ }^{11}$ treated the translating and popularizing activities of their teachers as a usual conduct, and joined this enterprise, though Serbian studies was not their main occupation by circumstances. ${ }^{12}$ While in the late 1990s, the very translators who mostly worked as teachers or scholars, wrote prefaces, reviews and reviewing articles of Serbian authors, later the textual traces of readers' reception from the outside began appearing more often. The philological and academic representation of the translated works was substituted by literary, critical and journalistic representation. This coincided with the process of media democratization, the decline of literary sections in the press and the transfer of the presentation and communication space to the Internet. Thus, the poetry of Z. Karanović was passionately debated by the Ukrainian community of the Living Journal. The online editions started playing a prominent role: first of all, it was LitAktsent, which still remains popular in the conditions of the increasing number of literary web-sites. It posts reviews of novelties in the Serbian literature (Z. Karanović's novel "Four Walls and the City"), including those which have not yet been translated into Ukrainian (Milorad Pavić's "Second Body" and Vladislav Bajac's „Hamam Balkanija”), round-table discussions devoted to the Serbian writers Mileta Prodanović and Dragoslav Mihailović.

Owing to the increasing number of translations from Serbian literature, they are reviewed not only by experts in Serbian literature. The change in the literary and critical scene is a sign of altering the forms of reception: Serbian literature is already

11 We can recall at least the publication of „Twelve Collections and the Teashop" by Zoran Živković as translated by a group of students at the Ivan Franko National University of Lviv (LA "Piramida", 2011).

12 Among the translators of today's Serbian literature, Natalia Chorpita is the only professional translator (she also translates from Croatian, English, Polish and other languages). Their main occupation is teaching (Mariya Vasylyshyn, Zoriana Huk, Natalia Khoroz, Khrystyna Stelmakh, Alla Tatarenko teach at the Ivan Franko National University of Lviv; Natalia Bilyk, Olena Derkach, Olena Dziuba-Pohrebniak teach at the Taras Shevchenko National University of Kyiv), research (Ivan Luchuk, Oksana Mykytenko, Veronika Yarmak are employed at the institutes of the National Academy of Sciences of Ukraine). Olena Kontsevych is a journalist and a regional representative of the Folio Publishers. The well-known Ukrainian writers Kateryna Kalytko and Andriy Lyubka translate from Serbian, too. 
well-known and interesting not only for the academia, but it is sufficiently valuable that readers of translations start writing about it. Serbian literature is gaining its readers in Ukraine, the circle of which is definitely narrower than that of admirers of "great" world literatures, but it expands at the expense of literature lovers who are more interested in a literary piece than in a certain national and cultural tradition. Books by Serbian writers are read from the standpoint of the European literary context, and recently, more often from the viewpoint of the cultural interests of Ukrainian readers.

This process is elucidated in the collection "Serbian Literature in the Ukrainian LitAktsent" (Ajdačić 2017). In addition to articles by translators of Serbian literature, there is a large number of reviews by young literary critics who are not specialists in Serbian language and literature, as well as interviews with Serbian writers (Dragoslav Mihailović, Mileta Prodanović, Srđan Srdić and Zvonko Karanović) and translator Alla Tatarenko. It is worth noting the increasing role of interviews as a genre relevant to representing a work of a certain writer or literature.

The character of the reception of Serbian literature in contemporary Ukraine consists in a certain systematic account of representative works from Serbian literature in the form of translations and information about them in Ukrainian and Serbian. A major role has been played by the online platform "Rastko" - the Serbian Literature On-Line Library (www.rastko.org.rs), - which was supplemented with the "Rastko Kyiv-Lviv" Library at the very beginning of the $21^{\text {st }}$ century. For a long time, with varying intensity (the peak of its activity was during the first years of its existence), there have been publications oriented at readers who are interested in Ukrainian-Serbian cultural connections. It posts Ukrainian translations of Serbian literature ${ }^{13}$ and Serbian translations of Ukrainian literature, academic monographs and articles, interviews and news of Serbian Studies in Ukraine and of Ukrainian Studies in Serbia. The director of this project and the curator of the library "Rastko Kyiv-Lviv" was Dejan Ajdačić, a Serbian Slavist and later Professor of the Department of Slavonic Philology at the Taras Shevchenko National University of Kyiv. He has implemented a number of initiatives aimed at intensifying the reception of Serbian culture in Ukraine, like the publication of the Ukrainian-Serbian almanac "Ukras"14. Each issue had its own topic which was important for Serbian and Ukrainian history or culture (Serbian immigrants in Ukraine, the life and activities of Nikola Tesla, Serbian literary avant-garde manifestos and so on). Leading experts from Ukraine and Serbia were invited to participate. The published articles covered various aspects of Slavonic Studies, as well as Ukrainian and Serbian culture. In the end, each issue published a chronicle of Ukrainian-Serbian cooperation in various

13 Some of them were posted primarily on the site "Rastko" on purpose.

14 Launched in 2006, published irregularly. The 2013 issue was not published in a paper version, but posted on the web-site «Rastko» (www.rastko.org.rs) 
spheres of culture. By publishing important information on Serbian culture and history in Ukrainian, reporting on the development of Ukrainian-Serbian contacts in these areas, the editorial board of the almanac contributed a lot to support and cordial relations between the two nations.

The chronicle of events, published in "Ukras", discloses a lot of interesting enterprises that deserve to be remembered and mentioned. However, in this article we will focus only on those phenomena which lasted long, created a certain tradition or contributed to changes in the reception of Serbian literature in contemporary Ukraine. One of them is an almost traditional participation of Serbian writers in the Lviv Publishers' Forum. Similarly, it is significant that the Kyiv Book Fair "Book Arsenal" was attended by Serbian writers S. Srdić, M. Pantić, M.Prodanović (2015) and Z. Karanović (2017). Meanwhile, let us return to the Literary Festival of the Lviv Publishers' Forum, as it is far more than the sporadic visits of the authors whose books come out in Ukrainian in a specific year. It can be defined as the annual "Serbian" element of the program. The Forum was attended by Goran Petrović, Mihajlo Pantić, Zvonko Karanović, Sava Damjanov, Ljubica Arsić, Aleksandar Jerkov, Srđan Sirdić, Slobodan Vladušić, Vladimir Kecmanović, Vida Ognjenović, Marija Midžović, Mirjana Novaković, Gojko Božović. Some of them were guests at the Festival several times. Literary readings, meetings with students, discussions, recitations of poetry along with interviews for journalists of Ukrainian editions promoted the acquaintance of Ukrainian readers with these authors and their writings. The better Ukrainian reception was also boosted by pair performances when Serbian authors recited in tandem with well-known Ukrainian writers. The first meeting with Zvonko Karanović was held during common readings with Serhiy Zhadan; Ljubica Arsić shared a reading with Yevheniya Kononenko; Sava Damjanov with Yuriy Vynnychuk. This approach minimizes the distance between a foreign writer and a Ukrainian reader and enhances an effective reception: admirers of a Ukrainian author have an opportunity to discover a new writer who is close to their nature and taste.

The Publishers' Forum invites both writers whose translated works are novelties of the year, and Serbian authors whose books have not yet been translated into Ukrainian. Participating in the Literary Festival is often their step towards Ukrainian readers and towards the publication of a translation. "Translation" is the key word in the title of this article, and translation is the key phenomenon of the reception of a foreign literature. Over the recent twenty years, a considerable number of separate editions of Serbian literature have come out in Ukraine. The circle of publishing houses, which include Serbian writings into their publishing plans, has been shaped. In the first decade of the $21^{\text {st }}$ century, one of the leaders was LA "Pirami$\mathrm{da}^{\prime 15}$; nowadays, the Publishing House "Tempora" keeps the leading position. The

15 The publishing house was awarded the Dositej Obradović Prize at the International Belgrade Book Fair (2013). 
publishing house "Knyhy XXI" is also interested in Serbian literature; "Komora's" translations of Serbian authors are popular with readers; "Folio" continues publishing translations from Serbian, as well. This group of publishers was joined by the "Anetta Antonenko" and "Apriori" Publishing Houses. The translations published in Ukraine are mainly works of contemporary Serbian literature or the classics of the second half of the $20^{\text {th }}$ century. An exception is Miloš Crnjanski's classic modernist novel "The Carnojevic Diaries" (translated by A. Tatarenko, LA "Piramida", 2015). If twenty years ago, Ukrainian intellectuals got acquainted with the creativity of D. Kiš via Polish translations and with the writings of M. Pavić via Russian translations, now we can claim that Ukrainian translations are the main source of acquaintance with Serbian authors. Some twentieth-century classics, which were previously published in Russian, finally came out in Ukrainian (Meša Selimović's "Death and the Dervish" (translated by K. Kalytko, "Kruhovert", 2017), Goran Petrović's "Smalltalk Place at 'Lucky Shot'" (translated by A. Tatarenko, "Komora", 2017)). The collection of Goran Petrović's stories "Differences" was published at first in Ukrainian as a part of the book "Island and Other Visions" ("Folio", 2007) and the Russian translation came out three years later. The Ukrainian translation of Danilo Kiš outpaced the Russian translation by 17 years: "A Tomb for Boris Davidovich" was published in Ukraine in 2000, while in Russia in $2017^{16}$. Thus, we observe the processes of making the Ukrainian publishing market independent from the influence of its nearest neighbours whose book production competed with the Ukrainian one too successfully for a long time and was a benchmark in the selection.

In Ukraine there are published writings by both celebrated writers and beginning authors for whom Ukrainian translations become their first editions abroad. Thus, in addition to the aforementioned, the cult works of Serbian literature came out: "When the pumpkins were blooming" by Dragoslav Mihailović (translated by M. Vasylyshyn, "Fakt", 2006), "New Jerusalem" by Borislav Pekić (translated by A. Tatarenko, "Kalvariya", 2007), "Rumour about Cyclists" by Svetislav Basara (translated by A. Lyubka, "Knyhy XXI", 2017). Readers received translations of wellknown contemporary prose writers like Milorad Pavić (translated by N. Chorpita, "Erotic Stories", "Folio", 2005), Goran Petrović ("Island and Other Visions", "Folio", 2007), Vida Ognjenovič ("Adulterers", translated by V. Yarmak, "Tempora”, 2012), Zvonko Karanović ("Four Walls and the City", translated by N. Chorpita, "Fakt", 2009; "Three Pictures of Victory", translated by Z. Huk, "Komora", 2016), Mihajlo Pantić ("If This is Love", translated by O. Mykytenko, "Tempora", 2012; "Walking in the Clouds", translated by K. Kalytko, "Tempora", 2015), Mileta Prodanović ("Ultramarine", translated by L. Nedashkivska, "Tempora", 2013; "Arcadia", translated by K. Kalytko, "Tempora", 2015), Filip David ("Reports of the Real and the Unreal”,

16 The first Ukrainian-language translation of D. Kiš («The Encyclopedia of the Dead») came out back in 1998. 
translated by O. Kontsevych, "Apriori", 2016). The younger generation of Serbian prose writers is presented in translations as well: Srđan Srdić ("Espirando", 2013; "Satori", translated by A. Tatarenko, "Komora", 2015), Srđan Valjarević ("Komo", translated by A. Lyubka, "Knyhy XXI", 2016), Vladimir Kecmanović ("Felix", translated by N. Khoroz, "Knyhy XXI", 2014), Uglješa Šajtinac ("Very Modest Gifts", translated by K. Kalytko, "Tempora", 2016). The rare samples of publishing books of translated poetry are the collection of selected poems by Zvonko Karanovic "Drums and Strings, the Highway and the Night" (translated by A. Tatarenko, "Piramida", 2011) and the collection of poems for children "Kitty in the Pocket" translated by Oksana Senatovych ("Navchalna knyha - Bohdan").

Serbian drama is represented by the collection "Contemporary Serbian Plays" (compiled by D. Ajdačić, Les Kurbas Centre, 2006), containing translations of works by Dušan Kovačević, Ljubomir Simović, Aleksandar Popović, Nebojša Romčević, Milena Marković, Biljana Srbljanović. A separate edition was the collection of plays by Nebojša Romčević "And now there should be the most important" (translated by A. Tatarenko and Z. Huk, "Tempora", 2014). The "Theatrical Series" of the "Anetta Antonenko Publishers" presented the translation of V. Ognjenović's drama "Mileva Einstein" (2017, translated by A. Tatarenko). D. Kovačević's "Professional" was performed on the Chamber stage of the Mariya Zankovetska Academic Theater in Lviv, and N. Romčević's "The Guilt" is still in the repertoire of Lviv's "Teatr u Koshyku".

A significant number of the Serbian translations mentioned above came out thanks to the support of the Ministry of Culture and Information of the Republic of Serbia, which for ten years has been organizing competitions for foreign publishers and sponsoring the publication of representative works of Serbian literature. This greatly facilitates the publication of Ukrainian translations. Only a small part of the translations came out without the financial support of the Ministry of Culture of Serbia, directly from the Minister of Culture or a certain fund or company.

The peculiarity of Ukrainian reception of Serbian literature is a large number of collective projects (anthologies, collections of stories, etc.) prepared by a group of translators. Their creative teams consist of university teachers and students, experienced specialists and beginners: this enables the latter group to start their translation career with working on difficult texts and receive appropriate guidance. Representatives of the two largest Slavist schools in Ukraine (Kyiv and Lviv) participate in these projects by working together on translating and creating a common field for reception.

The translators of Serbian literature in Ukraine often act as its popularizers. They take part in literary readings, which take place during festivals, fairs, as well as in presentations and meetings in bookstores of the largest Ukrainian bookshop network "Ye". Often, they author prefaces to the works of Serbian literature, interview Serbian writers, review Serbian authors and elucidate the development of today's Serbian literature. The most active practitioners are translators who combine trans- 
lating and the activities of a literary critic, journalist or writer. The appearance of young, but recognized and popular writers, like Andriy Lyubka and Kateryna Kalytko, among the translators of Serbian literature has raised the interest of Ukrainian readers in the literature of the Serbs. The interest in the creativity of these Ukrainian writers generates interest in the works they translate.

In recent times, the Internet, esp. social networks, is becoming a more important factor in the reception of literature. The "leaders of thoughts" in the literary and reading community greatly influence the choice of literature for reading by their subscribers and Facebook friends. Attention is attracted by new strategies for the visual evaluation of a literary piece: conceptual photographs with liked books, etc. The positive reception signal is the attention of popular bloggers and book reviewers, so in the context of the topic presented, we would like to note attention-grabbing video reviews of G. Petrović's novel "Smalltalk Place at 'Lucky Shot'” by Halyna Safronyeva and Liuda Dmytruk. Halyna Safronyeva's video blog offers plots on various topics, including books which are worthy of attention. Introducing Petrovićs novel to her audience, the former art-manager of the Lviv bookstore "Ye" brings it closer to readers by applying comparisons with well-known films that can be a separate topic for analyzing the reception of this work. Expressing her opinion about the "Smalltalk Place", Liuda Dmytruk points to a positive impression of the literary presentation: she claims that the moderator and literary critic Hanna Uliura along with the translator of the novel, Alla Tatarenko, directed its reception in different ways. The young literary reviewer points to the important role of presentations and literary readings for shaping new channels of readers' reception.

Beside the formal changes in the reception and presentation of Serbian literature in Ukraine, it is worth noting changes of a different nature related to non-literary factors. Before 2014, the translation of Serbian literature was the key to understanding another nation, searching for answers to universal human questions, but after the breakout of the War in Donbass in 2014, it started functioning as a mirror. Among the texts published within the past four years, there are many novels about the war and the post-war spiritual state of the human. Ukrainian readers are looking for answers to their questions about what should be done with the war which goes on within the person`s soul. The experience of a WWI participant, Miloš Crnjanski, is reflected in "The Carnojevic Diaries"; the experience of a participant in the $\mathrm{Yu}$ goslav Wars of the 1990s is examined in Z. Karanović' s "Three Pictures of Victory"; furthermore, in S. Srdićs novel, a war is a shadow which is hard to escape from. Ukrainian journalists asked these writers (visiting Ukraine in 2015, 2016, and 2017) not so much about their writings, but about the experience of Serbs' overcoming war traumas. The novels by Srđan Srdić and Zvonko Karanović along with the writings by Miljenko Jergović and Melina Kamerić are subject to artistic and thematic (sometimes also social and psychological) analysis in Oksana Shchur's article "The Balkan Nerve: Books about War in Ukrainian Translations" (Shchur 2015). The works of 
contemporary Serbian writers become the mirror in which Ukrainian readership wants to investigate its face.

ttum. Taras Shmiher

\section{BIBLIOGRAPHY}

Ajdačić Dejan et al. Serbski folklor i literatura v ukrainskyh perekladah i doslidzhenniah. 1837-2004. Kyiv: NBUV, 2005.

Ajdačić, Dejan. „Mnogoglasje ukrajinskog portala LitAkcent o savremenoj književnosti”. Srpska knjižernost u ukrajinskom LitAkcentu. Ur. D. Ajdačić. Beograd: Alma, Kulturna mreža “Projekat Rastko”, 2015. P. 9-20.

Ajdačić Dejan, ured. Srpska književnost u ukrajinskom LitAkcentu. 2. dop. izd. Beograd: Alma; Kijev: Tempora, 2017.

Ajdačić, Dejan."Ukrajinska srbistika - istraživači folklora i književnosti". Slavistika 11 (2007). P. 333-344.

Ajdačić, Dejan. "Ukrajinski pereklady ta perekladachi serbskoji literatury”. Slavistychni doslidzhennia: folklorystychni, literaturoznavchi, movoznavchi. Kyiv: VPC "Kyivskyj universytet", 2010. P. 13-32.

Ajdačić, Dejan. “Ukrajinski prevodioci srpske književnosti”. Slavistika 9 (2005). P. 372-380.

Lobur Nadiya, Motornyi Volodymyr, Tatarenko Alla. “Mosty mizhkulturnoji spivpraci: z perekladackogo dosvidu kafedry slovianskoji filologiji Frankovogo universytetu". Komparatyoni doslidzhennia slovianskyh mov i literatur: Pamiati akademika Leonida Bulakhovskogo 24 (2014). P. 323-331.

Nakhlik, Olesya. "Recept zberezhennia osobystoji ta nacionalnoji svobody vid polskogo pysmennyka Andzheja Bobkovskogo: ukrajinska recepcija vojennoho shchodennyka Vijna i spokij". Kyivski polonistychni studii XXIV (2014). P. 520-528.

Nakhlik, Olesya. “Ukrajinska percepciia ta recepciia prozy Cheslava Milosha“. Kyivski polonistychni studii XVI (2010). P. 443-457.

Ostapchuk, Viktoriya. “Ukrajinski pereklady Vislavy Shymborskoji jak recepcija: komparatyvnyi vymir". Sultanivski chytannia 5 (2016). P. 118-127.

Paščenko, Jevgenij. “Ukrajinska recepcija hrvatske i srpske književnosti tranzicijskog razdoblja”. Tranzicija i kulturno pamćenje. Ured.V. Karlić, S. Šakić, D. Marinković. Zagreb: Srednja Evropa, 2017. P. 81-92.

Paščenko, Jevgenij. Ukrajinsko-hrvatske književne poredbe. Split: Književni krug, 2010.

Paščenko, Jevgenij. Ukrajinsko-srpske veze u doba baroka. Banja Luka: KPUU Taras Ševčenko, 2004.

Savenets, Andriy. Poezija v perekladi: "ukrajinska" Shymborska. Lublin - Zhytomyr: Polissia, 2006.

Shchur, Oksana. “Balkanskyj nerv: knyzhky pro vijnu v ukrajinskyh perekladah". 2015. Web. 29.03.2018. <http:/ litakcent.com/2015/07/23/balkanskyj-nerv-knyzhky-pro-vijnu-v-ukrajinskyh-perekladah>

Tatarenko, Ala. “Magično kruženje knjiga: Danilo Kiš u Ukrajini”. Krajina 1 (2001). P. 155-161.

Tatarenko, Ala. "Milorad Pavić i njegovi ukrajinski čitaoci”. Letopis Matice srpske 478. 4 (2006). P. 690-699.

Tatarenko, Ala. "Susret kultura na granici milenijuma ili Ukrajinski izlet srpske književnosti". Sveske 64 (2002). P. 137-143.

Tatarenko, Alla. "Recepcija tvorchosti Milorada Pavycha v Ukrajini”. Problemy slovianoznavstva 53 (2003). P. 113-119. 